\title{
ABCB1 wt Allele
}

National Cancer Institute

\section{Source}

National Cancer Institute. ABCB1 wt Allele. NCI Thesaurus. Code C52273.

Human ABCB1 wild-type allele is located in the vicinity of $7 q 21.1$ and is approximately 210

$\mathrm{kb}$ in length. This allele, which encodes multidrug resistance protein 1, is involved in transmembrane transport. Amplification of the $A B C B 1$ gene is a major determinant in the development of multi-drug resistance, which decreases the effectiveness of many chemotherapeutic agents used in cancer treatment. 